\title{
"Incorrigíveis, afeminados, desenfreiados": Indumentária e travestismo na Bahia do século XIX
}

\author{
Jocélio Teles dos Santos ${ }^{1}$ \\ Departamento de Antropologia - UFBa
}

RESUMO: Nos registros policiais e nas notícias de jornais baianos oitocentistas encontram-se referências à prisão de travestis (a maioria homens que se "vestiam de mulher"). Utilizando-se de relatos de cronistas e viajantes para situar os modos de vestir e trajar na cidade de Salvador, o autor analisa os casos de travestismo abordando alguns temas correlatos, como o da homossexualidade e aspectos da vida baiana oitocentista. O argumento é que o percurso do travestismo no Brasil oitocentista dependeu das interelações entre as diferenciações dos trajes e a normatização dos papéis sexuais.

PALAVRAS-CHAVE: travestismo, vestuário, Bahia, século XIX. 
JocéLIo T.dos SANTOS. INCORRIGÍveIS, AFEMINADOS, DESENFREIADOS

Nos registros de rondas policiais da Bahia oitocentista, encontramse, além das costumeiras repressões aos ajuntamentos de escravos, batuques e candomblés, referências à prisão de homens que se "vestiam de mulher" e mulheres que se "vestiam de homem". Esse fato chama a atenção, já que por mais de três décadas, de 1853 a 1885 , várias prisões foram efetuadas por este "crime".

Os documentos que registram essas detenções não fornecem muitos dados para uma análise mais detalhada do fato em questão. Entretanto, apesar da escassez de informações, podemos extraí-los, através de outras fontes, como os relatos de cronistas e viajantes e as notícias de jornais baianos, elementos que possibilitam uma discussão acerca dos significados desta inversão simbólica que era os indivíduos se vestirem de acordo com os padrões do sexo oposto. Afinal, é de se notar, como faz Braunstein (1990:566), que o traje vai além do tecido e ornamento, estendendo-se ao comportamento, determinando-o e evidenciando-o, marcando as etapas da vida ${ }^{2}$, contribuindo para a construção da personalidade e distanciamento dos sexos, das classes, dos grupos étnicos, de status, de idade, etc.

Estamos perante um fato que revela a relação existente entre indumentárias. Uma oficial com padrões rígidos para ambos os sexos e uma outra divergente. Como conseqüência, encontramos deslocamentos e transformações dos elementos vestimentares constitutivos da ordem social dominante no mundo urbano no século XIX que serão definidas como transgressivas. Esta ordem abrangeria a gestão das aparências (sexuadas), a normatização do corpo (através da roupa, ou da ornamentação corporal e da cosmética de uma forma geral) e a regulação da sua visibilidade (nos espaços público e privado).

Deste modo, poderíamos dizer que a roupa, ou o seu uso como marcador social/sexual, os jogos simbólicos diferenciadores-indicadores que envolvem o vestir-se (e o travestir-se) devem ser considerados numa perspectiva não somente estética, ou de moral privada, mas 
de moral pública e de Direito, situando-se já na intersecção entre a sociedade civil e o Estado.

Trata-se, neste nível, de algo que diz respeito à decência, aos bons costumes, às convenções hegemônicas (o que convém e é conveniente), à discrição, às boas maneiras inerentes à vida civil, englobando-se no amplo "processo civilizador" de que trata magistralmente Norberto Elias.

A normalidade vestimentar passou a ser uma dimensão da vida cotidiana, cada vez mais regulamentada pelo Estado, através da legislação e de instituições especializadas destinadas ao controle do espaço público urbano (envolvendo em especial pobres, as classes "perigosas" e os desviantes em geral), constituindo-se num campo de intervenção que tendeu a um domínio próprio - objeto dos poderes de polícia a partir do século XIX $\mathrm{X}^{3}$. Tornou-se uma ordem vigiada e punitiva, e não mais normatizada apenas pelo próprio corpo social, pelos mecanismos tradicionais do pudor, da vergonha, da maledicên$\mathrm{cia}^{4}$ e do ridículo.

E é assim que a transgressão dessa normalidade passou a ser objeto de uma atenção especial, constituindo-se não mais uma questão meramente costumeira, mundana, se não como uma falta moral, como um delito. A própria natureza da documentação (leis, regulamentos, notícias policiais dos jornais locais) é bem significativa da concepção de travestismo que tinham as nossas elites.

\section{As vestes em corpos "naturais"}

A indumentária é um elemento simbólico fundamental na definição das nossas identidades, não só de classe mas também de gênero. Como conseqüência, a moda irá manifestar padrões, limites, imposições tácitas de ordens diversas, estabelecendo projeções típicas de comportamento para todas as categorias de indivíduos, fixando um conjunto de significações e valores de um modo sistemático. Daí a formulação 
JocéLIO T.dos SANTOS. INCORRIGÍveIS, AFEMINADOS, DESENFREIAdos

estruturalista de Roland Barthes (1967), que considerava a moda um sistema relativamente fechado, semanticamente perfeito e largamente naturalizado pelas pessoas - representando uma espécie de "direito natural".

Deste modo, evidencia-se que a diferenciação das vestimentas, segundo os sexos, é um elemento central nos diversos tipos de travestimento, tanto cerimonial (Bateson, 1971) quanto lúdico (por exemplo, carnavalesco), prostitutivo ou privado. Como quer que seja, trata-se sempre de transformações episódicas , periódicas ou, excepcionalmente, permanentes, operadas a partir de um código cultural pré-estabelecido.

Nesse sentido, as relações desiguais entre os gêneros têm no corpo o seu primeiro suporte simbólico, sobre o qual exerce-se uma vigilância severa ao tempo em que é exibido. A indumentária traduz-se, então, como signo distintivo do lugar ocupado pelos diferentes corpos sexuados.

Em um estudo direcionado para a moda do século XIX, Gilda de Mello e Souza (1987:58s) observa que a vestimenta numa sociedade patriarcal acentuará o antagonismo existente entre o homem e a mulher, criando duas "formas" regidas por princípio completamente diversos de desenvolvimento. Isto faz com que a história do traje se diferencie tanto para o homem quanto para a mulher: "a indumentária masculina evoluiu na sua trajetória de oblongo em pé, sólido dos ombros aos tornozelos, ao segmento de uma estrutura assemelhandose no desenho a um $\mathrm{H}$. A feminina tomou como símbolo básico de sua construção um X" (Id., ibid.).

A distinção do vestuário masculino e feminino, que Gilberto Freire (1987b) classificava como "modos de homem" - circunscritos ao "jeito, artes e comedimentos próprios de homens bem educados", e "modas de mulher" expressando a imagem da feminilidade - estabelecia imagens e projeções de comportamentos para todos os indivíduos. Ao fixar normas e padrões de vestuário para cada um dos sexos, 
não se permitiam mudanças, ou mesmo inversões de indumentária. Essa era a própria semantização do corpo.

Esse fato pode ser notado no que Laver (1990:182) chama de "complexo das calças": a tentativa das mulheres, no período pós-1840, em usar calças, além de ter provocado agitação, gracejos e censuras, foi considerado um ataque ultrajante à posição masculina. Adotar um símbolo da identidade viril significava transgredir os signos de sedução, charme e metamorfose do vestuário feminino. Mas, paradoxalmente, a moda, ao menos sobre a base dos sexos, como lembra Lipovetsky (1989:133), permanece essencialmente não-igualitária: o pólo masculino ocupa sempre a posição inferior, estável, em face da mobilidade livre e proteiforme do feminino.

Convém observar que mesmo numa sociedade escravocrata, como a baiana do século XIX, a indumentária para escravos (as) e senhores (as) passava por uma "padronização sexual" semelhante. Assim, mesmo existindo uma hierarquia social, que revela a forma de vestir através de signos da posição social, usar roupas de acordo com o próprio sexo constituía algo que estava além das diferenciações sociais.

Isto não quer dizer que essa uniformização fosse de todo obedecida. Desde o século XVIII, como diz Vilhena (1969:54), as senhoras eram ditas como "pouco honestas" e criticadas "por andarem dentro de suas casas em mangas-de-camisas, com golas tão largas, que muitas vezes caem, e se lhes vêem os peitos". Pela narrativa dos viajantes oitocentistas podemos observar que no interior das casas ocorria o uso de roupas poucas e leves, refletindo o modo "impróprio e indecente" de se "trajar em casa", enquanto que no espaço público imperava o pudor, a discrição, a formalidade (Augel, 1980:221).

A visita matutina da inglesa Maria Graham (1990:168), em 1821, às casas de senhoras portuguesas, "metade delas eram senhoras da sociedade", mostra a sua repugnância por não vê-las usando coletes, espartilhos, lenços ao pescoço e mangas nos vestidos; a escritora de- 
JocéLIo T.dos SANTOS. INCORRIGÍveIS, AFEMINADOS, DESENFREIADOS

monstrou surpresa quando em reuniões sociais, à noite, encontravaas não mais "desmazeladas", mas vestidas à moda francesa, com corpete, enfeites, fichu (mantilha), e exibindo suas jóias (:175).

A distinção entre o vestuário masculino e o feminino, que estava presente na sociedade brasileira desde o século XVI, acentuou-se no século XIX quando se estabeleceu, por exemplo, as calças brancas para advogados, professores, médicos, altos funcionários públicos (Freire, 1987:416), cartola e sobrecasaca para os estudantes de Direito e de Medicina, a sobrecasaca e a calça de feltro, de vincos laterais, pespontados e salientes, para os senhores de engenho, e os vestidos de tafetá preto, de aba rodada, arrastando no chão, recoberto por capota, com mangas compridas até às mãos, para as senhoras da burguesia açucareira nordestina (Freire, 1964:99 passim).

É importante notar que, no espaço público, as senhoras brancas eram reservadas - usando sedas, veludos , fitas e jóias - enquanto os varões exibiam excesso de bordados, lantejoulas nos coletes, rendas nas roupas de baixo e adereços (Lindley apud Araújo, 1993b:119). Também algumas escravas mostravam exuberância nos seus modos de vestir, como registra Vilhena (1969:54), no século XVIII, ao observar as mulatas e pretas que acompanhavam suas pomposas senhoras: "vestidas com ricas saias de cetim, becas de lemiste finíssima, e camisolas de cambraia, ou cassa, bordadas de forma tal, que vale o lavor três, ou quatro vezes mais que a peça; e tanto é o ouro, que cada uma leva em fivelas, cordões, pulseiras, colares ou braceletes, e bentinhos, que sem hipérbole, basta para comprar duas, ou três negras, ou mulatas como a que o leva: e tal conheço eu que nenhuma dúvida se lhe oferece em sair com quinze, ou vinte, assim ornadas." 6

No século seguinte, o príncipe Maximiliano de Habsburgo (1982 (1860): 81s) ao encontrar em Salvador uma escrava que despertou a sua atenção, pelo contraste com as negras que vendiam frutas usando "roupas leves e descuidadas", notava que o seu corpo encontrava-se 
em perfeita harmonia com todo o conjunto: "vestia o traje pitoresco e admirável das negras brasileiras [...] uma saia de chita estampada com flores vivas cai, folgada e descuidadamente, em volta das ancas, que balançam suavemente. Uma bata branca, sem manga, esvoaça, como peça casual, na parte superior do corpo. Ao andar pela cidade, um xale colorido aberto e pregas graciosas, cobre-lhe os ombros".

É curioso que, além de "um torço de tecido leve, branco ou azul-claro", a escrava usava um colar (ou colares?) que poderíamos identificar como signo distintivo do universo religioso afro-baiano: "contas de vidro com amuletos profanos pendem em longas voltas sobre o peito". Mas, quem eram essas negras tão suntuosas? É possível que se tratassem tanto de escravas, pois as grande famílias se preocupavam em demonstrar a sua opulência até mesmo pela riqueza dos ornamentos usados por seus escravos domésticos ${ }^{7}$, quanto de libertas, visto que a posse de jóias para estas, segundo Oliveira (1988:47), constituía uma parcela importante dos bens que deixavam em testamento. Segundo Nina Rodrigues (1977:119), eram chamadas, já pós a abolição, de "negras ricas" e usavam sandálias, algo distintivo da qualidade de libertas: "carregam o vestuário à baiana de ricos adornos. Vistosos braceletes de ouro cobrem os braços até ao meio, ou quase todo; volumoso molho de variados berloques, com a imprescindível e grande figa, pende da cinta. A saia é então de seda fina, a camisa de alvo linho, o pano da Costa de rico tecido e custosos lavores; completando o vestuário especiais sandálias que mal comportam a metade dos pés." 8

Obviamente que nem todas as escravas e libertas demonstravam riqueza no seu vestuário e nem se vestiam do mesmo modo. De acordo com Nina Rodrigues (1977:118s), os crioulos, particularmente as mulheres, adotavam e conservavam vestuários de origem africana. Enquanto os negros usavam vestes brancas, de grosso tecido de algodão, calça e camisa justa e curta, as mulheres vestiam "saias de cores vivas, de larga roda. O tronco coberto da camisa é envolvido no pano 
Jocélio T.dos SANTOS. INCORRIGÍveIS, AFEMINADOS, DESENFREIAdos

da Costa, espécie de comprido chalé quadrangular, de grosso tecido de algodão, importado da África. O pano da Costa passa a tiracolo, sobre uma espádua, por baixo do braço oposto, cruzadas na frente as extremidades livres". O uso desse traje combinado com o "torso, triângulo de pano cuja base cinge a circunferência da cabeça, indo prender-se as três extremidades na parte posterior ou nuca", teria como resultado a qualificação de "baiana".

Entre as africanas sobressaíam, pelas descrições dos viajantes, as negras minas. De acordo com Robert Avé-Lallemant (1980:23), estas traziam o busto coberto com "frouxa camisa branca que, justamente por ser muito larga na parte superior, põe um ombro e o seio quase nus. A orla de cima da camisa é, muitas vezes, ornada de bico branco e toda em tecido tão diáfano e este, ainda por cima, sobretudo aos domingos, enfeitado com tantos bordados vasados, que todo o busto de basalto negro transparece, deixando advinhar-lhes as formas"10.

Os escravos se vestiam de variadas formas, da exuberância à simplicidade, como pode ser deduzido, por exemplo, dos relatos e das fotografias da época (Filho, 1986; Freire, 1979). Podiam mesmo estar quase nus nos mercados, em que eram vendidos, com apenas "um pequeno pedaço de pano grosseiro em volta da ancas" (Rugendas, 1979:256). Ali, a providência imediata do comprador de escravos era vesti-los com "roupas que lhe agradem: a faixa de variegadas cores, que lhe enrolam em torno da cintura, o paletó de lã azul e o boné vermelho" (Rugendas, 1979:258; Graham, 1990:170) ${ }^{11}$.Vê-se o quanto era significativo para a sociedade escravocrata a utilização de vestes que permitissem estabelecer uma nova condição ao escravo. Não mais o escravo dos mercados, sem vestes, portanto em estado "selvagem", mas o escravo vestido e identificado socialmente como de pertencimento a alguém. A ritualização de vesti-lo tinha, assim, o objetivo de retirá-lo da sua completa "nudez social" e marcá-lo no seu devido lugar. 
Por consequiência, haveria uma legislação específica sobre vestuário. A postura da Câmara Municipal de Salvador, de 11 de maio de 1859, estabelecia pena de quatro mil réis e dois dias de prisão, para "qualquer indivíduo livre ou escravo empregado em serviço de carregamento" que não estivesse vestido (Repertório de Fontes, 1988:82). O objetivo era enquadrá-los em trajes que refletissem a ordem sistêmica do vestir no seu aspecto do decoro. Não é à toa que, ao narrar o fato de um homem de "cor preta" ter sido impedido por um padre de ir além das grades de uma igreja, o jornal O Alabama destacava o fato desse estar - "vestido com decência" ${ }^{12}$. Um outro dado vai nessa mesma direção. Em dezembro de 1869, o periódico destacava a presença de crioulas em uma missa por elas estarem muito "chiques" 13 .

A postura baiana não era isolada. Coadunava-se com preocupações em âmbito nacional. No Maranhão, por exemplo, encontramos leis, no período que vai de 1843 a 1884 , estabelecendo pena de mil reis, "que se dobrará quantas vezes reincidir", para "toda pessoa livre, ou escrava que for encontrada nas ruas, e praias desta villa ou em estradas públicas, vestidas de modo que offenda a decência e moral pública" (Collecção de Leis, Decretos 18351884). Uma punição maior, com prisão de oito dias, apareceria em 30 de setembro de 1846, para aqueles que andassem a qualquer hora "do dia, ou da noite em camisa e ceroula ou mesmo com a camisa solta por cima das calças". O curioso é que a multa de seis mil réis diminuía para dois mil réis quando o contraventor fosse escravo, já que havia uma determinação no artigo para o senhor fazer o pagamento. No entanto, a multa permanecia em seis mil réis quando o escravo fosse reincidente. Nota-se desse modo como a legislação, refletindo a preocupação com a moral pública, distinguia condição social ao mesmo tempo que pressionava os senhores de escravos a implementar a proibição. 
JocéLIo T.dos SANTOS. INCORRIGÍveIS, AFEMINADOS, DESENFREIADOS

Apesar da legislação não conter nenhum dispositivo explicitamente jurídico para a proibição de homens e mulheres se vestirem como o sexo oposto, o Código Criminal do Império do Brasil permite algum tipo de interpretação que nos faz pensar a questão da inversão da indumentária como um caso relacionado à moral e ao decoro público, estando, portanto, sujeita à ação policial. O seu artigo 280 prescrevia a prisão de dez a quarenta dias, e multa correspondente "à metade do tempo", àqueles que tivessem praticado "qualquer ação que na opinião pública sejam considerados evidentemente offensivos da moral e bons costumes" (Silva, 1859). É possível que, sendo o catolicismo a religião oficial do Estado, a transgressão do vestir-se como o sexo oposto encontrava base de apoio no Deuteronômio 22:5 que diz "a mulher não se vestirá de homem nem o homem se vestirá de mulher, porque aquele que tal faz é abominável diante de Deus".

É revelador que a transgressão a que se refere o artigo 280 fosse definida no âmbito de um comportamento público. Assim, a polícia apoiou-se nesse dispositivo para prender, por exemplo, José Ferreira Pacheco, em 4 de maio de 1853, por se encontrar "vestido de mulher"14. Mas, ao mesmo tempo, infringia o próprio artigo, pois a repressão aos travestidos ocorria também em espaços privados, como podemos inferir por um ofício policial de 22 de abril de 1885 , em que o indivíduo Pelino Bahiense da Silva Freire, dizia que à noite, "sobre sua casa" , na rua Ariani, localizada na Baixa do Bonfim, apareciam homens vestidos de mulher. Segundo a autoridade policial os denunciados não haviam sido encontrados ${ }^{15}$.

Infelizmente, não encontramos maiores informações sobre os travestidos da Baixa do Bonfim. A pergunta que decorre dessa denúncia é se por estas plagas não estariam a ocorrer, ou melhor, a se "reproduzirem" ruidosas reuniões de travestis portugueses, chamadas por sua algazarra, de "grandes pagodes", na Lisboa do século XVI (Mott, 1988c) ${ }^{16}$ ? 
Mas, quais as razões dos atos persecutórios da polícia aos costumes vestimentares que vemos se desenhar na Bahia do século XIX?

Inicialmente, devemos atentar para o fato de que a polícia, como observa Robert D. Storch (1985), em um estudo direcionado para a polícia urbana na Inglaterra vitoriana, havia sido redefinida para atuar como um instrumento polivalente da disciplina urbana, e que a sua implantação tinha como objetivo a manutenção do decoro nas ruas. Isso implicava preocupações com a ordem social que, no caso baiano, se manifestavam em vigilância contra ajustamentos de escravos, intervenção em brigas e proibição de tomar banho sem roupas, principalmente, nas fontes públicas.

Devemos também pensar que a repressão sistemática aos travestidos compreendia uma dimensão mais ampla, envolvendo uma possível polarização entre o público e o privado, ou mesmo a definição de um outro estilo de vida urbana - supostamente mais "moderno", "burgês". O que pressuporia maneiras (inclusive de vestir) mais "discretas", "higiênicas", "civilizadas", etc., conformando-se a modos de vida oriundos dos centros de referência europeus então hegemônicos ${ }^{17}$.

Norbert Elias (1990:24) já observava que no conceito de civilização encontramos tudo que a sociedade ocidental procura circunscrever e aquilo de que se orgulha, como por exemplo a natureza de suas maneiras. Isto é deveras importante, na medida em que podemos perceber na padronização da indumentária masculina e feminina baiana oitocentista numerosos ecos de outros lugares.

A definição de um vestuário, principalmente masculino, difundiuse e consolidou-se na Europa, como mostra Francesco Alberoni (1982:50), depois da revolução burguesa de 1848: " a revolução francesa não conseguira produzir um único modelo capaz de resistir: os diferentes modelos populares e nobiliárquicos tinham acabado por impor-se novamente, até mesmo sob a restauração, mas já a nova classe, então consolidada e segura de si, provia a elaborar um estilo pró- 
prio de vestuário, dir-se-ia quase 'uniforme' que, por fim viria esmagar todos os outros reduzindo-os a objetos carnavalescos ou folclóricos ou a indicadores de marginalidade e desvio social" ${ }^{18}$. As transformações representadas pelo triunfo do mundo do capitalismo industrial, a hegemonia burguesa e desenvolvimento dos ideais individualistas-democráticos, modificaram os antigos trajes cotidianos, distintivos das populações urbanas e rurais, das classes sócio-econômicas, dos grupos de status, das classes etárias, dos gêneros. Como conseqüência, foram sendo redefinidos aqueles empregados em momentos festivos, em situações de "inversão ritual".

Em Bradford, por exemplo, e em outras partes do norte da Inglaterra, haviam os "mascarados", grupos de homens e adolescentes com os rostos pintados de preto, vestidos freqüentemente em trajes femininos (ou às vezes mulheres vestidas de homem), que costumavam invadir os distritos da burguesia, na véspera do ano novo, pedindo dinheiro ou cerveja e carregando vassouras para "varrer" o ano velho (Storch,1985:18). Com o argumento de que estas práticas eram formas de extorsão ou de violação da paz, a polícia tentava impedir essas manifestações.

Se, no episódio citado, a Inglaterra fornece um exemplo de que havia uma conjugação da subversão tanto simbólica (o travestismo ritual), quanto social - afinal de contas as pessoas provinham dos bairros operários -, como pensar essa mesma questão em Salvador? Na velha cidade, os que desafiavam a indumentária vigente também eram socialmente marginalizados. Esse dado é muito importante na medida em que se nota uma nítida conjugação da inversão simbólica do vestir com a posição do indivíduo na hierarquia social. Estávamos perante situações que, como no caso do Rio de Janeiro (única cidade brasileira na época que podia rivalizar com a outrora opulenta Bahia), "a ação da polícia e as atitudes de seus agentes dependiam, sem dúvida, da posição sócio-econômica e do grau de prestígio dos cidadãos e das famílias" (Araújo, 1993:305). 
Exemplos desse fato foram as prisões do mendigo Manoel Francisco e da prostituta Carolina Maria Ferreira Maia. Em 22 de fevereiro de 1854, Manoel Francisco foi detido porque "vagava pela cidade vestido de mulher" 19 . O seu travestismo encontrava ressonância numa provável subversão social, já que, como observa Walter F. Filho (1986:40), os mendigos eram vistos tanto pela ótica da piedade, condizente com sua posição social, quanto pela repulsa e intolerância, pois representavam uma ameaça à ordem social.

No mesmo dia da prisão de Manoel Francisco, um registro policial publicado no Jornal da Bahia, afirmava ter sido presa a meretriz Carolina Maria Ferreira Maia, parda, de 17 anos, por ter sido encontrada na rua às duas horas da noite em "trajes de homem" ${ }^{20}$. Note-se que Carolina carregava consigo vários estigmas: a prostituição, o travestismo, o gênero e a cor.

Qual a razão de Carolina andar pela madrugada travestida? Observe-se que muitas mulheres saíam à noite, vestidas de homem, para passarem despercebidas. As suas vestes seriam mais um disfarce que uma transgressão à moral vigente. Diante desse dado, o travestismo de Carolina pode ser qualificado como pragmático-funcional que se difere de um pragmatismo-simbólico dos que se travestiam a qualquer hora do dia ou da noite, como era o caso de Antonia, moradora no centro da cidade:

“- Capitão, sabe mais de uma?

- Agora.

- Anda por esta cidade uma mulher vestida de homem.

- De veras?

- De veras. Uma tal Antonia moradora à rua direita de Palácio, n'um sobrado de três andares.

- Bom!

- A rapariga, não se contenta de transformar-se à noite, sem a menor cerimônia sobe à rua de dia em trajes masculinos.

- Si ha por ahi tantos homens que podiam andar de saia, pouco admira que uma mulher queira suprir-lhes o logar." ${ }^{21}$ 
JocéLIo T.dos SANTOS. INCORRIGÍveIS, AFEMINADOS, DESENFREIADOS

A cor da prostituta Carolina é relevante pois aponta a maior presença de afro-baianos entre os que subvertiam a ordem do vestuário. Um exemplo foi a prisão da lavadeira Maria Archanja da Conceição, cor cabra, em 20 de agosto de $1871^{22}$. Entretanto, também encontramos uma referência à prisão de uma branca, costureira, Francelina Olympia da Rocha por ser encontrada vestida de homem ${ }^{23}$.

\section{Desvarios dos incorrigíveis e das desenfreadas}

Isto posto, uma pergunta que poderíamos levantar na análise dos boletins de ronda policial é: de que modo podemos perceber nos indivíduos presos uma transgressão também no campo da sexualidade? Essa questão é instigante pois apenas um único documento policial aponta, implicitamente, a imbricação da "subversão" simbólica do vestir com a preferência sexual.

Foi o caso do africano livre João Paulo, em 25 de abril de 1865. João Paulo, que havia sido encontrado "dentro das matas próximas ao Barbalho" vestindo "camisa de algodão e saia de mulher", e apresentando "diversos ferimentos", aparece em um boletim de ocorrência policial sob a denominação de "incorrigível" pelo fato de já ter sido punido, pelo mesmo motivo, sem alterar o seu comportamento ${ }^{24}$.Esse termo já aparece desde o século XVI, em Portugal, como designativo dos homossexuais reincidentes (Mott, 1988c:126). Sabemos que desde o século XVI, no Brasil colonial, já se encontravam homossexuais que se travestiam de mulheres, como foi o caso do africano Francisco do Congo. Esse sapateiro transgredira duplamente o Direito Canônico, por crime de sodomia e por "fingir ser de diferente estado e condição". Dizia as Constituições Primeiras do Arcebispado da Bahia (1711:939 e 958): "o homem que se vestir em traje de mulher pagará 100 cruzados e será degredado para fora do Arcebispado da Bahia arbitrariamente, conforme o escândalo que der e efeitos que resultarem"(apud Mott, 1988a:34). 
Apesar dos documentos policiais não serem informativos sobre o "incorrigível" João Paulo, encontramos nas notícias de jornais do século XIX fatos bastantes curiosos que envolvem, explicitamente, tanto a transgressão do vestir quanto a homossexualidade.

Michel Foucault (1985), em História da Sexualidade I, afirma que o homossexual, enquanto categoria, é criação dos higienistas no afã de classificar, nomear e indicar um lugar social para os diferentes tipos de perversões que vieram à tona em plena moral vitoriana. Alguns estudos sobre o homossexualismo no Brasil do século XIX afirmam que a ciência médica, na tentativa de codificar essas "anormalidades" sexuais, inventou no final desse século a figura do "pederasta" como sinônimo de homossexual (Fry, 1982:34). Entretanto, anteriormente a este período, o termo já aparecia carregado do mesmo sentido como se observa numa nota do jornal O Alabama, em edição de 11 de setembro de 1870, em que um homem casado com uma "virtuosa esposa pouco feliz" foi tachado de "mau filho, mau esposo, mau pai, mau tio, jogador corrupto, sevandija consumado e...pederasta paciente" 25 . Para tantas qualificações que permeariam a "escola do vício" desse personagem anônimo, era esperado "o golgotha da expiação de sua libertinagem pois morte de cruz será a condemnação de suas nefandas orgias".

Embora o uso do termo pederasta fosse importante para designar aqueles que tinham o "instinto sexual" impelido para o sexo a que pertencem (Id., ibid.), importa notar que as notícias da imprensa revelam muito mais as práticas sexuais do que dominações ou categorizações, como podemos notar através de um ofício publicado em 18 de junho de 1867, chamando atenção, e pedindo "providências", ao Chefe de Polícia para um "insolente e incorrigível moleque de nome Horacio, escravo, morador à Fonte das Pedras, o qual seduz os meninos para fins libidinosos de parceria com um outro, também escravo, de nome Cosme, além de muitas outras immoralidades que poem em 
Jocélio T.dos SANTOS. INCORRIGÍveIS, AFEMINADOS, DESENFREIAdos

prática; e si alguma pessoa tracta de desviar os pobres innocentes incautos expõe-se aos maiores insultos destes dous desenfreiados"26.

As práticas homossexuais na capital baiana não se restringiam ao universo masculino. Havia também notícias sobre o homossexualismo feminino. De todo modo, é bastante curioso que faltem nas notícias sobre lesbianismo a qualificação e a conceituação desenvolvidas com relação aos homossexuais masculinos. Havia ou não uma terminologia oficial específica para as lésbicas ou atos lésbicos? Mesmo que os termos "lésbios", "sáfico", "tríbade", que aparecem no final do século, tenham sido exclusivos de juristas e médicos preocupados em classificar práticas sexuais não condizentes com a moral vigente (Mott, 1987:44), creio que o evidenciado no período colonial por Bellini (1987:39), possa nos servir de parâmetro para os jornais baianos: em relação à sodomia tinha-se como critério a anatomia masculina como referência, e a falta de um vocabulário e conceitos precisos obscureceram as tentativas de compreender o modo como podia ser cometida por mulheres.

É esclarecedor a publicação de uma matéria pelo jornal O Alabama, em 8 de março de 1870, que demonstra a perplexidade da imprensa perante uma relação de "íntima camaradagem" entre duas mulheres na rua do Colégio. O fato chegou a ser noticiado por causa do escândalo provocado pela seríssima briga entre "as duas amigas", conforme transcrevemos abaixo:

“- Capitão, estou atterrado.

- O que foi que o pôz nesse estado?

- Um facto do mais execrando sacrilegio que o delírio humano pode pôr em prática.

- Conte-me o que ha.

- Na rua do Collegio, uma mulher conhecida por Bella [destaque do jornal], vive em intima camaradagem [id.] com uma outra.

- No domingo beberam muito; à noite, Bella, embriagada dos sentidos pelo vinho e da alma pelo vício, querendo entregar-se a excessos de seus incontinente gênio, convidou para isso sua companheira que 
excusou-se dizendo que não estava disposta. Primeiro usou de palavras brandas e affectuosas caricias e afagos para conseguir o que desejava; mas não o alcançado, Bella, no auge da hallucinação, egual a bestafera que se vê contrariada em seus brutaes apetites, da de mão a uma navalha para coagir sua companheira e compartilhar de se sensual deboche. Depois de estriptosa assuada que despertou a attenção de quem passava, houve entre as duas amigas [id.] esta troca de palavras:

'- Bella, por aquella Senhora, (e apontou para uma Imagem da Conceição) me deixe.

- Por esta!...(e da bocca da reproba sahiu a mais horrorosa imprecação contra a Imagem) não te deixo.'

E acto continuo, lançou mão de Imagem da Santissima Virgem, e com ella fez tiro a face de outra!!...

- Meu Deus! isto é horrendo! Só por um vertiginoso desvario. Mas como sabe V. cousas que se passam de portas à dentro?

- O facto foi quasi publico porque a vozeria fez que se reunisse gente e quasi toda visinhança presenciou".

A leitura da imprensa demonstra a surpresa pelo episódio ter-se tornado público. Afinal de contas, estava-se perante um fato que deveria se passar "portas à dentro". Por outro lado, houve um sacrilégio, pois a imagem da Santíssima Virgem não somente foi jogada contra o rosto da íntima amiga de Bella, como foi usada num contexto que refletia desvario, devassidão e vício.

Curiosa é a forma como o jornal induz o leitor a saber da relação entre as "duas amigas". Através do uso de grifos em palavras que ora destacam, ora eufemizam os fatos, observa-se, e também revela-se, a razão da alucinação e do "sensual deboche" de Bella. Trata-se, portanto, de uma linguagem que beira a discrição - "intima camaradagem", "sua companheira", "duas amigas" - mas que se associa a um certo naturalismo descritivo, pois a fúria de Bella é destacada pelos seus excessos - "brutaes apetites", "incontinenti gênio", "auge da hallucinação". A denúncia do jornal passava, portanto, do tom pitoresco da narrativa para a explicação de um amor beligerante. 
Um outro fato que se inscreve nesta mesma direção é uma notícia reproduzida do jornal chileno El Mercurio, três meses antes do episódio de Bella. O jornal O Alabama, ressaltando ser um "processo curioso", destacava em edição de 12 de dezembro de 1869 , um casamento entre duas mulheres, em junho de 1869 , o seu posterior julgamento e anulação pelos tribunais do Chile. A matéria revelava que o casal havia enganado a "sogra e todas as pessoas da família" visto que o "famoso casamento" ocorrera "há 14 annos". Como isso foi possível? Segundo o jornal, uma das mulheres havia "fingido-se" de homem, "nesse longo espaço de tempo". Algo a destacar, é que quando levadas à justiça, "persistiam em declararem-se marido e mulher"27.

A curiosidade com que a imprensa trata do insólito processo me parece mais sintomático pelo casamento realizado do que pelas práticas sexuais aí presentes. Nesse sentido, creio que se pode deduzir tanto das narrativas do casamento chileno, quanto do desejo desenfreado da baiana Bella, o seguinte: as relações homossexuais femininas que a imprensa revela, a forma e o modo como são qualificadas, apontam para uma reprovação menos exaltada do que aquela adstrita ao universo masculino. Essa maior tolerância para com o erotismo entre as mulheres, em relação ao existente entre os homens, serviria, talvez, para reafirmar a virilidade cobrada destes enquanto um exercício potente e freqüente, que nunca diz não. Virilidade como condição do sujeito masculino, portador de um corpo adestrado para um erotismo "desenfreado", direcionado idealmente para o sexo oposto.

Se existia uma tolerância com o travestismo masculino era, exclusivamente, no âmbito das representações teatrais presentes no país desde o período colonial (Trevisan, 1986:136-143). Já na vida cotidiana , particularmente quando associado à homossexualidade masculina, o travestismo era explicitamente relacionado à ação policial. A razão, me parece, é que enquanto os travestidos masculinos se expunham publicamente, comprometendo o decoro e a moral nas ruas do 
centro da cidade, fazendo com que o homossexualismo ficasse completamente às claras como prática social, o simbolismo ritual e o vestimentar próprio ao comportamento lésbico, pela própria condição em que viviam as mulheres baianas do século XIX encontravam-se mais em domínios privados. Além do mais, em uma sociedade patriarcal, o questionamento de códigos sexuais institucionalizados, que a homossexualidade e/ou travestismo masculino trazia em si, revelava uma maior ameaça ao ethos dominante. E isso fica claro no modo como a imprensa baiana tratava os episódios já relacionados e aqueles que vamos apresentar a seguir.

Duas notícias, dos anos de 1866 e 1870, demonstram como o comportamento de homossexuais baianos revelava uma certa subversão dos signos vigentes, seja na forma de se vestir ou no uso de objetos que eram exclusivos das mulheres. No dia 25 de setembro de 1866, o jornal $O$ Alabama, através de um ofício ao delegado de polícia, informava que na rua dos Carvoeiros morava um crioulo conhecido por José do Ouro, sócio do Jovita, o qual tinha o desaforo de "por-se nu em casa, amarrar um lenço à cabeça, a laia de crioula, deitar argollas nas orelhas, coraes nos braços, embrulhar-se n'um chalé ou panno da costa e ir para janella". Observando que o "effeminado taful" entrava na sua morada, desembrulhando-se e "expondo-se neste estado à vista da família" que morava defronte, o ofício solicitava ao delegado, "em nome do decoro", a "correção merecida" ao "desavergonhado" José do Ouro. Observa-se que o fato de José do Ouro "ir para janela", podia significar, implicitamente, o comportamento das prostitutas, ou "mulheres de janela", que se debruçavam nas janelas dos sobrados para provocar os "senhores moços" que passavam (Soares, 1992:41s).

A segunda notícia refere-se a outro "affeminado", anônimo, que o jornal O Alabama, em 29 de outubro de 1870, dizia ir para a escola "com os bolsos cheios de pomada, pó de arroz, escovinha de dentes e espelho para se mirar ante a casa dos curandeiros". Seria essa casa 
JocéLIo T.dos SANTOS. INCORRIGÍveIS, AFEMINADOS, DESENFREIADOS

um terreiro de candomblé? É possível que sim, já que muitos pais e mães-de-santo na Bahia oitocentista eram qualificados como curandeiros e/ou feiticeiros. O certo é que, segundo o jornal, o anônimo "affeminado" por contar com a "proteção de bambu [uma bengala] do curandeiro R.S.", não ia às sabatinas, não era chamado "à leção e espera ser approvado". Esse fato é deveras interessante pois revela a inserção de homossexuais em um terreiro de candomblé na cidade do Salvador. Deduz-se que, desde o século XIX, os terreiros não discriminavam o indivíduo pela sua origem social, ou pelas práticas eróticas e objetos de desejo. Muito pelo contrário, supomos que a categoria adé, que se refere ao homossexual "do santo" ( Birman, 1985:5), já estaria presente no plano religioso.

A proteção a que se refere o jornal pode ser traduzida como algo já institucionalizado naquele universo religioso e que estaria muito além de uma simples solidariedade estabelecida entre marginalizados - líderes religiosos e "affeminados" 28 .

Pelas matérias coletadas pode-se perceber que, nos anos sessenta e setenta do século passado, era significativa a presença de homossexuais que se travestiam pelas ruas da Bahia. Um deles, o vadio conhecido com "Yaya Mariquinhas" era um exemplo da "offensa permanente a moralidade publica" já que "se dava até para querer transformar o sexo, usando de trajes de mulher" nas ruas e "portaria de S. Francisco". Com o intuito de conter a ousadia de Yaya Mariquinhas, o delegado Freitas Henriques havia mandado prendê- $10^{29}$.

Transparece nessa matéria a imbricação de duas marginalizações sociais - o travestismo e a condição de vadio - que estavam a dessacralizar as relações de poder na sociedade de antanho. Assim como o travestismo era uma prática social incompatível com o estabelecimento de padrões e normas sexuais, ser vadio significava, como bem observa Walter F. Filho (1986:94) , situar-se fora da ordem estabelecida pois violava o ideal patriarcal - ter seu lugar, uma família e seu senhor. 
Algo curioso é a possibilidade do mutante ter adotado publicamente o nome feminino. E perguntaríamos, até que ponto a inversão da linguagem - a dominação de Yaya - não se tornou nele mais significativa que a inversão corporal? Seria a inversão da figura gramatical de designação sexual mais refratária que a sua inversão do vestir?

Um fato interessante, nos anos setenta, foi a descoberta de um travestido nos Aflitos. Havia ele aparecido "vestido de mulher" e conquistado um rapaz. Posteriormente, um "gaiato" descobriu de que se tratava de um "ex-voluntário de 54" (provavelmente algum batalhão militar). O que se sucedeu foram bordoadas de "diversos rapazes" no corajoso travestido, o rasgar da sua roupa e a chegada da polícia que, curiosamente, puniu os rapazes. A ação policial pode ser compreendida menos pela defesa do travestido e mais pelo fato ter se transformado em uma anarquia.

"Ha creaturas que entendem forçar os preceitos da natureza.

No domingo, no fogo dos Aflictos, appareceu um homem vestido de mulher. Um gaiato, vendo aquella mulher e suppondo ser alguma menina feliz [grifo do jornal], foi bachuleal-a e encontrou-se com o rigoroso infano [id.]. Descobriu porem o engano em que estava, e viu que a supposta mulher era um ex-voluntario do 54.

Reuniram-se diversos rapazes e pozeram a roupa do affeminado [id.] em tiras, sendo a saia levada feito bandeira por um dos sujeitos, que o esbordoaram. Eis por fim apresentou-se a polícia, e por sua vez espancou também o povo.

- Que terra, meu Deus!"30

Além do termo "affeminado", a imprensa usava a expressão "homem-mulher" para definir os travestidos. Essa expressão era corriqueira na Bahia oitocentista, como podemos notar na matéria, em forma de diálogo, sobre um travestido baiano, publicada no jornal $O$ Alabama em 13 de julho de $1871^{31}$. 
“- Capitão, na terça-feira andou um homem pela rua de Baixo de São Bento, vestido de mulher, com saia preta e camisa branca!

- A que horas?

- Às sete da noite, pouco mais ou menos.

- E não o prenderam?

- Passando n'essa ocasião o ordenança do subdelegado, e sendo chamado para prender o homem-mulher, negou-se, desculpando-se que ia levar a familía do subdelegado ao espetáculo.

- E assim esta terra; no entanto que bem podia estar encoberto debaixo das vestes femininas algum criminoso.

- Que dúvida! Mas eu supponho que era força de pifão.

- Fosse lá o que fosse, competia à policia verificar a razão por que o indivíduo havia transformado os trajes!"

A matéria é elucidativa pois revela o fato da sociedade baiana haver, algum tempo, dado conta da existência de travestidos, mas que fingia ser um fato novo, como dizia o Jornal da Bahia. É importante notar que se a imprensa pedia a ação da polícia para coibir a ação dos travestidos, imaginando tratar-se de um recurso utilizado para possíveis crimes - "bem que podia estar encoberto debaixo das vestes femininas algum criminoso"-, também usava uma linguagem jocosa para mostrar a confusão sobre o uso de determinadas vestes para alguns indivíduos. É ilustrativo o caso de um "pobre caipira" que procura um advogado. Na matéria intitulada $\mathrm{O}$ doutor mulher, seção Variedades, do jornal $O$ Alabama do dia 2 de julho de 1871, percebe-se a "estranheza" do caipira perante o uso de um chambre pelo "doutor leis". O que está implícito na matéria é que, na sociedade baiana, o travestismo tinha também se tornado alvo de brincadeiras e gracejos entre os homens. Observa-se a forma como o advogado, já vestido com um chambre, responde a indagação do caipira sobre o doutor. O modo como o texto é descrito leva-nos a crer que o "doutor leis", simulando ser uma mulher, usou de falsetes e trejeitos femininos para brincar com o caipira: 
"Um pobre caipira foi a casa de um doutor em leis, para encarregal-o de uma causa importante e como este se achava na rua, o caipira foi recolhido a uma sala por uma preta, que lhe disse, que esperasse o doutor que não tardaria a chegar. Com effeito, passado cinco minutos, entrou o doutor de casaca, chapéu, etc. Era ainda moço, gordo, e sem barba; saudou o caipira e dirigiu-se para o interior da casa a mudar de fato.

D'alli ha pouco apareceu elle de chambre, e o pobre do caipira, suppondo que a mãi ou a mulher do mesmo, levantou-se, com todo o respeito, dizendo: 'Boas tardes, sinhá dona. aqui estou à espera do Sr. doutor'. Este que era algum tanto capadócio, acudiu de prompto: 'Elle apanhou uma constipação no despir-se, e por isso mandou-me em seu logar. Sentemo-nos e conversemos'. 'Nha não', tornou o caipira meio sorrindo-se , 'eu virei depois; o negócio e cabelludo, não se pode fazer patente a mulheres.",

Para melhor ilustrar a argumentação de que a perseguição policial aos travestidos era acompanhada pela imprensa através de uma linguagem que explicitava algo de "novo" no comportamento baiano do século XIX, assim como por revelar o tom de se estar diante de um fato digno de zombaria, passemos a mais uma "notícia" publicada em $O$ Alabama em 22 de abril de 1871. É interessante atentar que nessa matéria aparece o verbo transformar, que, no século XX, vai ser indicativo do que fazem os travestis "transformistas" que trabalham em boates, casas de espetáculos ou em programas de TV. Outro dado ali presente, que indica o motivo das outras prisões efetuadas pela polícia, é que os travestidos saíam em quaisquer dias da semana e geralmente à noite:

“- Você que gosta de passear à noite pela Estrada Nova, veja lá.

- Quando estou nos meus destinos. Mas o que ha lá para ver?

- Homens vestidos de mulher.

- Novas de caminho.

- Pensa que é gracejo. Na quarta-feira, às onze horas e meia da noite, foi preso um indivíduo vestido de mulher.

- Isso é de veras?

- Um pouco mais adiante da cachoeira do Para-assú. O indivíduo 
JocéLIo T.dos SANTOS. INCORRIGÍveIS, AFEMINADOS, DESENFREIADOS

não trazia armas, declarou chamar-se Francisco, e que se transformara (destaque do jornal) por graça. Dessas graças não venha cá não. Pelo menos podia estar ali à espera de algum desses rapazes que quando encontraram mulher à noite gostam de acompanhal-a, e que fosse cahir n'alguma cilada."

A notícia que nos fornece maiores informações sobre o travestismo no Brasil está numa matéria do Diário do Rio de Janeiro, entitulada "Homem-mulher", transcrita pelo Jornal da Bahia em 25 de abril de 1875. Qual a razão para tão bizarro título? E por que o jornal dizia ser um caso "por sua natureza novo entre nós"?

A referida matéria tratava de um episódio envolvendo a prisão de um rapaz chamado João, pardo, 22 anos "presumíveis", que teria "formas mais ou menos regulares de voz affeminada". João, que no seu segundo depoimento não soubera dizer se era livre ou escravo, apesar de que anteriormente teria dito ser livre, houvera sido preso na freguesia do Engenho Velho, na casa de uma família à rua Uruguaiana, esquina com a General Câmara, onde, através de uma agência portuguesa, tinha se alugado como criada com o nome de Rosalina.

Encontrava-se João (ou Rosalina?) na referida casa por quatro dias, "exercendo as funcções de mucama", quando, segundo o periódico, "quiz o acaso que um menino que o vio despir-se descobrisse o segredo e d'elle desse parte a seo pae, que, por sua vez, o entregou a polícia".

O fato que tenha conseguido passar tanto pela agência de aluguel de escravos quanto pela família como sendo Rosalina, e não João, é revelado, segundo a matéria, pela facilidade como ele "movia-se desembaraçadamente (...) em trajes de mulher"; o mesmo não ocorria quando usava roupas masculinas já que se mostrava "acanhado e tropego no andar" parecendo não estar à vontade - à sonaise [grifo do jornal].

Mas, além dos trajes de mulher o que compunha a persona Rosalina? Tendo os cabelos "metido em um invisível" ${ }^{32}$ e preso por um pente 
denominado vulgarmente travessa", envolvia-se num xale e usava uma "pequena almofada de algodão para fingir seios".

Toda a sua indumentária repousava em uma profunda identificação com o sexo oposto. É o que transparece no primeiro depoimento de João, quando este afirma categoricamente que "pertencia ao sexo feminino e, entre outras provas que apresentava allegou ter tido há pouco um mao sucesso". O que seria esse "mao sucesso"? Alguma experiência traumática que o levou a uma identificação radical com o mundo das mulheres?

Apesar de ficar obscuro, o jornal dá o destaque à expressão "mao sucesso", o que por si só já indica algum tipo de importância: a afirmação de João é elucidativa do ponto de vista de uma identidade construída, pois devido à pressão (e possivelmente repressão) policial, João irá dizer em um depoimento posterior ao $2^{\circ}$ delegado que "com effeito era homem".

Se essa declaração denota para ele uma leitura morfológica do seu próprio corpo, assim como o caráter flutuante da identidade do travesti (Silva, 1993:91), ou o que Oliveira (1994:103), metaforicamente, chama de "auto imagem metamorfoseada", convém notar a afirmação de que desde "tenra idade andava vestido de mulher" e que já havia trabalhado há algum tempo como criada em outras "casas de família".

A esse último dado deve ser acrescido o fato de que veio de Arauama (Araruama?) para o Rio de Janeiro, vestido de mulher, em companhia de "Bernadino de tal conhecido pelo charuteiro", e que viveu na casa de Bernadino durante dois anos trabalhando como criada, sempre vestido de mulher, sabendo este "ser elle homem".

Por "soffrer maos tratos", deixou a casa de Bernadino e passou a trabalhar em Barra do Paraí como cozinheira de "alguns trabalhadores de estrada de ferro" para posteriormente ser "alugada como criada em diversas casas de família".

O episódio de João (ou Rosalina) ainda revela alguns pontos que podem se coadunar com as prisões relatadas anteriormente. Ser par- 
JocéLIO T.dos SANTOS. INCORRIGÍveIS, AFEMINADOS, DESENFREIAdos

do, que o jornal vai caracterizar como sendo "cor africana", é importante tanto por expressar a sua inserção social quanto pelo fato de que vai ser a dessemelhança que o periódico notará com o "herói de Louvet" dos romances de Alexandre Dumas Filho.

Um outro ponto é a dificuldade em defini-lo tanto morfologicamente quanto socialmente. João é dito homem-mulher no sentido de dubiedade dos seus trejeitos e modos, mas, enquanto indivíduo, é qualificado como sendo do sexo masculino na "condição de criada"ou "posição de criada". Essa dificuldade da identificação do sujeito que se traveste pode ser percebida no imaginário social do século XIX. Em trechos da matéria, o jornal indagava se não seria João um impostor na medida em que ele adentrava em lugares que, em certas ocasiões, só às mulheres era permitido. E perguntava "será elle auxiliar de alguma quadrilha de ladrões"? Essa questão revela a constante associação dos travestidos com criminosos comuns. Isto demonstra a "novidade"do fenômeno e a sua complicada classificação.

A centralidade do simbolismo na vida humana tem sido reiterada por diversas correntes sociológicas e antropológicas recentes. Nesse sentido, podemos dizer que só quando nos deparamos com estranhos é que tomamos consciência de que, sem o conhecimento do seu código, não podemos entendê-los, pois todos os comportamentos com base no costume (e não só o ato de falar) transmitem informações (Leach, 1978:15). Acredito que não é por acaso que as definições dos documentos policiais para os travestidos se resumiam às expressões "encontrado vestido de mulher" ou "encontrada vestida de homem". Por isso, também, a dificuldade de definir tanto o transsexual carioca quanto os travestidos baianos. Homem ou mulher? Simplesmente homemmulher. Mas, caberia uma indagação. Por que não mulher-homem, já que "Rosalina"apresentava-se perante os olhos externos como tendo trejeitos bastante femininos, passando inclusive por mulher nas casas em que trabalhou? Pelo olhar policial ou da imprensa o que vai 
defini-lo, fundamentalmente, é a sua anatomia sexual e não a sua auto-identificação. Por isso, em primeiro lugar homem, depois, hifenizando-o, mulher.

Nessa direção, observamos que se a ordem e o decoro são importantes como categorias que imprimem traduções do sistema oficial da indumentária, a definição terminológica do que os subverte é por demais necessária. O vestuário como mostra Umberto Eco (1989:15), fala, possui um valor significativo de comunicação e está assentado sobre códigos e convenções, muitos dos quais são fortes, intocáveis, definidos por sistemas de incentivos ou sanções. Afinal de contas, se o vestuário como observa Martinet (1974), tem uma função de informação sexual, estava-se perante indivíduos que subvertiam os signos do vestir.

Parece-me que os sistemas de representações oficiais do século XIX, que podem estar tanto nas sumárias informações das prisões contidas nos documentos de ronda policial, quanto nas matérias transcritas de O Alabama e o Diário do Rio de Janeiro, por se encontrarem perante um fato novo que por si só era subvertor de ordens vigentes, exigiam através da investigação policial a sua averiguação. Leia-se, também, repressão.

O percurso do travestismo no Brasil oitocentista pode ser verificado, portanto, pelas interrelações entre as diferenciações dos trajes e a normatização dos papéis sexuais. Era o imaginário sobre o corpo jogando com signos de comportamentos e costumes considerados indecorosos.

Quando encontramos exemplos de indivíduos transgressores do vestuário e da sexualidade, em documentos policiais e notícias de jornais, é como se estivéssemos diante da prova cabal de que a repressão da sociedade não impedira essas personagens de cruzarem as ruas e, posteriormente, de atravessarem o século. Suas histórias cotidianas, marcadas por constantes atos repressivos, vinham à tona como se estivessem a nos anunciar a sua coragem, ousadia e atrevimento. 


\section{Notas}

1 Em sua versão final, este trabalho contou com a colaboração de Roberto Albergaria (UFBa.). Sou grato também a Neuza Oliveira, João J. Reis, Antonio Sérgio Guimarães, Vagner Gonçalves da Silva, Vivaldo da Costa Lima e Luís Mott pela leitura atenta, críticas e indicações bibliográficas, e a Claúdio Pereira por ter me emprestado textos valiosos.

2 Ou mesmo da morte, como mostra Reis (1991) em análise sobre o guarda-roupa fúnebre na Bahia oitocentista. Ver especialmente caps. 5 e 6.

3 Desde os anos finais do século XVII, e até o início do século XVIII, vemos se desenhar uma intervenção colonial sobre o vestuário no Brasil. Havia uma preocupação do governo português em criar uma legislação, através de cartas régias enviadas ao governador geral e a governadores de capitanias brasileiras, sobre os trajes, por exemplo, das escravas (Lara, 1995) .

4 Como ocorreu desde a Idade Média com o uso das listras vestimentárias consideradas depreciativas, pejorativas ou nitidamente diabólicas (Pastoreau, 1993:12).

5 Expressões encontradas em $O$ Alabama, 5/9/1871.

6 É curioso que o bem trajar dos escravos não constituía uma preocupação dos senhores em todo o país, como nota Scarano (1992), nas Minas Gerais do século XVIII. É possível que o observado por Vilhena tenha sido um reflexo de desenvolvimento urbano da cidade de Salvador, no qual a suntuosidade das senhoras e o bem vestir das suas escravas fossem um parâmetro das marcas da nossa proximidade com os países europeus.

7 Como visto na citação de Vilhena, e em Verger (1981:222).

8 Gilberto Freire (1990:101) observa que havia uma proibição aos negros, e aos escravos, do uso de jóias e de tetéias de ouro, com o intuito de marcar as diferenças de raça e de classe. A permissão se dava às "mucamas bem vestidas e cheias de jóias", pois estas "representavam um prolongamento das suas iaiás brancas quando exibiam em festas de igreja ou de 
rua". E foi em festa, na Igreja de Nossa Senhora da Conceição da Praia, que Roberto Avé-Lallemant (1980:48), em 1859, viu os enfeites de ouro de algumas negras. A combinação exótica de contas africanas com correntes de ouro deixara fascinado o viajante francês: “...é genuinamente africano um rico colar de corais, com enfeites de ouro, em volta do pescoço negro dessas mulheres. Muitas trazem grossas correntes de ouro ornando-lhes o colo. Vi uma com o antebraço coberto até ao cotovelo de braceletes articulados". Dois outros viajantes, os alemães Spix e Martius (1981:144), também registraram o uso de correntes de ouro e prata pelas escravas, "especialmente às escravas dos ricos fabricantes de açúcar, que, na elegância domingueira, realçam com o brilho dessas correntes as saias de cassa branca e lindas rendas".

9 Segundo Ramos (1979:198), a figura típica da baiana seria de influência nigeriana (os panos vistosos, as saias rodadas, os xales da Costa, os braceletes, os argolões), muçulmana (a rodilha ou turbante) e angola-congolenses (miçangas e balangandãs).

10 Sobre o modo de vestir das negras minas ver também Affonso, J., Três séculos de moda - 1616-1916. Belém, Tavares Cardoso, 1923 apud Ferretti, Sérgio F. Tambor de Crioula. Ritual e Espetáculo. São Luís, SECMA/Lthograf, 1995, p.58s.

11 A variedade na indumentária dos negros pode ser notada através das observações de J.da Silva Campos (1946:292) sobre o vestuário dos "ganhadores", dos trabalhadores do cais e dos trapiches: "usavam os 'ganhadores' ou trabalhadores do canto, no serviço diário, vestimenta de pano de algodão grosso (de sacos de farinha de trigo (ou de 'saco' ou aniagem tecido de juta usado em sacaria, servindo especialmente naquele tempo para enfardamento de xarque)). Eram estas as peças de indumentária: calças curtas de cós (de enfiar), que desciam uns $0 \mathrm{~m} 10$ abaixo dos joelhos e camisolão comprido, que lhes vinha até os joelhos, tendo dos lados bolsos de dois palmos de profundidade. Os trabalhadores do caes e dos trapiches usavam o tal camisolão sem mangas. À cabeça traziam em vez de chapéu um gorro de pano de algodão grosso, que lhes servia ao mesmo tempo de rodilha, quando houvessem de transportar objetos. (...) Toda essa indumentária era preparada pela negras." Note-se uma hierarquia social no vestuário da po- 
Jocélio T.dos SANTOS. INCORRIGÍveIS, AFEMINADOS, DESENFREIADOS

pulação de origem africana e dos seus descendentes: "africano que usava calças, paletó, chapéu e botinas era sujeito endinheirado".

12 O Alabama, 19/04/1871.

13 O Alabama, 12/12/1869.

14 Arquivo Público do Estado da Bahia (APEBa.), Maço 3117, Polícia (Assuntos).

15 APEBa., Maço 2975, Chefes de Polícia (1885).

16 Ainda a esse respeito, há que se notar a grande diversidade de formas de travestismo da história européia, intimamente associada à evolução das formas de sociabilidade cotidiana, da representação dos papéis e identidades sociais-sexuais tanto no espaço da vida familiar quanto mundana. Assim, podemos dizer que o travestismo na França, até o século XIX, se constitui como um fenômeno eminentemente teatral, festivo, lúdico. $\mathrm{O}$ próprio sentido dicionarizado da palavra indica isso: "disfarçar-se sob o traje de um outro sexo, de uma outra condição social", "fantasiar-se para uma festa ou um papel de teatro".

17 A respeito da "influência" do modelo civilizatório francês no âmbito das nossas elites locais, ver Azevedo (1985:26).

18 As roupas, assim como a linguagem e os serviços prestados, se convertiam em critério de patriotismo no ambiente sócio-político da Revolução Francesa (Hunt, 1991:240). Além de ser, como observa McLuhan (1988:142), um manifesto não-verbal de subversão política. Segundo Köhler (1993:463), entre 1791 e 1792, "ricos e pobres tinham o cuidado de vestir-se da maneira mais despojada possível, pois qualquer pessoa cuja aparência a colocasse sob a suspeita de ser um aristocrata corria risco de vida". Um exemplo marcante da nova indumentária francesa foi a substituição, pelos republicanos, dos aristocráticos calções (colantes, até os joelhos), pelas burguesas calças (folgadas, até os tornozelos); daí a expressão sans-culottes usada para identificá-los. De todo modo as diferenças sexuais nas roupas, a partir do final do século XVIII, teve como resulta- 
do uma transformação da indumentária masculina. Os homens abdicaram de seu direito a formas claras, alegres, elaboradas e mais variadas de ornamentação, deixando-as inteiramente para o uso das mulheres, fazendo assim o seu corte de roupa a mais austera e ascética de todas as partes (Flugel, 1966:100). Sobre as tendências magnificentes do vestir masculino e feminino durante o império napoleônico, ver Kemper (1977:cap.7)

19 Jornal da Bahia, 22/2/1854.

20 Jornal da Bahia, 22/2/1854.

21 O Alabama, 18/2/1869.

22 Diário da Bahia, 25/8/1871.

23 Jornal da Bahia, 9/3/1869.

24 APEBa, Maço 2959, Chefes de Polícia.

25 A qualificação "pederasta paciente" pode ser lida como a "sodomia passiva", que se distinguiria da "sodomia ativa". Sobre o "reconhecimento" público dos sodomitas passivos, seus hábitos, gestos, modo de vestir e maneiras de se "portar" ver Soares (1992:73).

26 O Alabama, 18/6/1867.

27 O Alabama, 12/12/1869.

28 Refiro-me às próprias representações religiosas contidas no universo da mitologia afro-brasileira que dão conta de entidades bissexuais. No final do século XIX, o escritor Xavier Marques, no romance $O$ Feiticeiro, já chamava a atenção para a bissexualidade da divindade Obatalá. Era o que Nina Rodrigues (1977:220) chamava a atenção como a concepção andrógina dos nagôs. Essas representações chegavam ao nível da indumentária ritual pois usava-se saias para os orixás masculinos e femininos. 
29 O Alabama, 24/1/1868.

30 O Alabama, 4/11/1870. Se o episódio dos Aflitos aponta para a existência de travestidos que havia servido ao corpo de voluntários, é interessante notar que era comum jovens se disfarçarem de mulher para livrar-se do recrutamento ( $O$ Alabama, 2/1/1864). Foi essa a justificativa que Joaquim Manuel de Macedo, no seu romance Mulheres de Mantilha, encontrou para explicar o travestismo da personagem Isidora (o) "que trajava vestidos feminis", cantava delicadamente o lundu, ornamentando e iluminando o oratório, mas que era na verdade um "lindo jovem". Em relação ao gênero feminino ocorreu o uso do travestismo para fins de alistamento. Foi o exemplo de Maria Quitéria que no início da Guerra da Independência entrou para o Regimento de Artilharia e passou a ser chamada "Soldado Medeiros" (Mott, 1987:40).

31 O designativo homem-mulher não era de uso exclusivo do Brasil. Aparece na França, como pode ser visto na obra de Marcel Proust, Em Busca do Tempo Perdido.

32 Rede de cabelo, muito fina, com que as senhoras amparam a parte frisada do penteado; grampo muito fino para os cabelos (cf. Dicionário Aurélio B. de Hollanda Ferreira).

\section{Bibliografia}

\section{ALBERONI, F.}

1982 “Observações sociológicas sobre o vestuário masculino”, Psicologia do vestir, Lisboa, Assirio e Alvim, $2^{\mathrm{a}}$ ed.

ANAIS DO ARQUIVO DO ESTADO DA BAHIA

Salvador, Imprensa Oficial, v.29, pp. 289-309.

ARAÚJO, E.

1993 O teatro dos vícios. Transgressão e transigência na sociedade urbana colonial, Rio de Janeiro, José Olympio. 
ARAÚJO, R.B. DE

1993b A vocação do prazer: a cidade e a família no Rio de Janeiro republicano, Rio de Janeiro, Rocco.

AUGEL, M.P.

1980 Visitantes estrangeiros na Bahia oitocentista, São Paulo, Cultrix.

AVÉ-LALLEMANT, R.

1980 Viagens pelas províncias da Bahia, Pernambuco, Alagoas e Sergipe: 1859, Rio de Janeiro/Belo Horizonte, Itatiaia/Edusp.

AZEVEDO, T.

1985 A francesia baiana de antanho, Salvador, Centro de Estudos Baianos - UFBa.

BATESON, G.

1971 La cérémonie du Naven, Paris, Minuit.

BARTHES, R.

1967 Système de la mode, Paris.

BELLINI, L.

1987 A coisa obscura. Mulher, sodomia e inquisição no Brasil colonial, São Paulo, Brasiliense.

BRAUNSTEIN, P.

1990 “Abordagens da intimidade nos séculos XIV-XV”, in História da vida privada, Ariès, P. e Duby, G. (orgs.), São Paulo, Cia. das Letras.

CAMPOS, J. da S.

1946 "Ligeiras notas sobre a vida íntima, costumes e religião dos africanos na Bahia”

COLLEÇÃO DE LEIS, DECRETOS E RESOLUÇÕES DA PROVÍNCIA DO MARANHÃO

1835 - 1884 Maranhão, Tipografia Constitucional. 
JocéLIO T.dos SANTOS. INCORRIGÍveIS, AFEMINADOS, DESENFREIADOS

ECO, U.

1989 “O hábito fala pelo monge”, in ECO, U. Psicologia do vestir, Lisboa, Assirio e Alvim.

ELIAS, N.

1990 O processo civilizador. Uma história dos costumes, Rio de Janeiro, Jorge Zahar.

FILHA, S.O.

1989 A fotografia e o negro na cidade do Salvador. 1840-1914, Salvador, FCEBa./EGBa.

FILHO, W.F.

1986 Mendigos, moleques e vadios na Bahia do século XIX, São Paulo/Salvador, Hucitec/Edufba.

FLÜGEL, J.C.

1966 A Psicologia das roupas, São Paulo, Mestre Jou.

FOUCAULT, $\mathrm{M}$.

1985 História da sexualidade I. O cuidado de si, Rio de Janeiro, Graal.

FREIRE, G.

1964 Vida social no Brasil nos meados do século XIX, Recife, MEC/ Instituto Joaquim Nabuco de Pesquisas Sociais.

1979 O escravo nos anúncios de jornais brasileiros do século XIX, São Paulo/Recife, Ed. Nacional/Instituto Joaquim Nabuco de Pesquisas Sociais.

1987a Casa grande \& senzala, Rio de Janeiro, José Olympio.

1987b Modos de homem e modas de mulher, Rio de Janeiro, Record.

1990 Sobrados e mocambos, Rio de Janeiro, Record, $8^{a}$ ed.

FRY, P.

1982 "Léonie, Pombinha, Amaro e Aleixo: prostituição, homossexualidade e raça em dois romances naturalistas", Caminhos cruzados. Linguagem, Antropologia e Ciências Naturais, São Paulo, Brasiliense. 
Revista de Antropologia, São Paulo, USP, 1997, v. 40 nº2.

GRAHAM, M.

1990 Diário de uma viagem ao Brasil, São Paulo/Minas Gerais, Ed. Itatiaia/ Edusp.

HUNT, L.

1991 "Revolução Francesa e vida privada”, in ARIES, P. \& DUBY, G. (orgs.), História da vida privada, vol. 4, São Paulo, Companhia das Letras.

KEMPER, R.H.

1977 A history of costume, New York, Newsweek Books.

KÖHLER, C.

1993 História do vestuário, São Paulo, Martins Fontes.

LARA, S.H.

1995 Sob o signo da cor: trajes femininos e relações raciais nas cidades do Salvador e do Rio de Janeiro, CA. 1750-1815, trabalho apresentado na reunião da Latin American Studiens Association, Washington.

LAVER, J.

1990 A roupa e a moda. Uma história concisa, São Paulo, Cia. das Letras.

LEACH, E.

1978 Cultura e comunicação, Rio de Janeiro, Zahar.

LIPOVETSKY, G.

1989 O império do efêmero. A moda e seu destino nas sociedade modernas, São Paulo, Cia da Letras.

MARTINET, A.

1974 "La fonction sexuelle de la mode", La linguistique, vol. 10, fasc. 1, PressesUniversitaires France.

MARQUES, X.

1975 O feiticeiro, São Paulo, GRD/Brasília, INL, $3^{\text {a }}$ ed. 
JocéLIO T.dos SANTOS. INCORRIGÍveIS, AFEMINADOS, DESENFREIAdos

\section{McLUHAN, M.}

1988 Os meios de comunicação como extensão do homem, São Paulo, Cultrix.

MOTT, L.

1987 O Lesbianismo no Brasil, Porto Alegre, Mercado Aberto.

1988a Escravidão, homossexualidade e demologia, São Paulo, Icone.

1988b O sexo proibido: escravos, gays e virgens nas garras de Inquisição, Campinas, Papirus.

1988c "Pagode português: a subcultura gay em Portugal nos tempos inquisitoriais", Ciência e Cultura, 40(2); 120-139.

OLIVEIRA, M.I.C.

1988 O liberto: o seu mundo e os outros, 1790/1890, Salvador, Corrupio.

OLIVEIRA, N.M. DE

1994 Damas de paus. O jogo aberto dos travestis no espelho da mulher, Salvador, CED -UFBa.

PASTOREAU, M.

1993 O pano do diabo. Uma história da listras e dos tecidos listrados, textos de Erudição \& Prazer, Rio de Janeiro, Jorge Zahar.

RAMOS, A.

1979 (1935) As culturas negras no novo mundo, São Paulo, Brasiliana.

REIS, J.J.

1991 A morte é uma festa. Ritos fúnebres e revolta popular no Brasil do século XIX, São Paulo, Cia. das Letras.

REPERTÓRIO DE FONTES SOBRE A ESCRAVIDÃO EXISTENTES NO ARQUIVO MUNICIPAL DE SALVADOR

1988 As Posturas (1631/1889), Salvador, Fundação Gregório de Matos/Prefeitura Municipal de Salvador.

RODRIGUES, N.

1977 Os africanos no Brasil, São Paulo, Ed. Nacional, 5a ed. 
Revista de Antropologia, São Paulo, USP, 1997, v. 40 nº2.

RUGENDAS, J.M

1979 Viagem pitoresca através do Brasil, Belo Horizonte, Itatiaia, São Paulo, Edusp.

SCARANO, J.

1992 "Roupas de escravos e de forros", Resgate - Revista de Cultura n ${ }^{\circ}$, Campinas, Papirus.

SILVA, J.N.

1859 Código criminal do império do Brasil, Rio de Janeiro, Eduardo Henrique Laemmert.

SILVA, H.R.S.

1993 A Invenção do feminino, Rio de Janeiro, Relume Dumará.

SOARES, L.C.

1992 Rameiras, Ilhoas, Polacas... A prostituição no Rio de Janeiro do século $X I X$, São Paulo, Ática.

SOUZA, G. DE M.

1987 O Espírito das roupas. A moda no século dezenove, São Paulo, Companhia das Letras.

SPIX, J.B.V. \& MARTIUS, C.F.P.

1981 Viagem pelo Brasil: 1817-1820, Belo Horizonte/São Paulo, Itatiaia/ Edusp, 3 vols.

STORCH, R.D.

1985 "O policiamento do cotidiano na cidade vitoriana”, Revista Brasileira de História, v.5, n. 8/9.

TREVISAN, J.S.

1986 Devassos no paraíso, São Paulo, Max Limonad.

VERGER, P.

1981 Notícias da Bahia - 1850, Salvador, Corrupio. 
JocéLIo T.DOS SANTOS. INCORRIGíveIS, AFEMINADOS, DESENFREIADOS

\title{
VILHENA, L.S.
}

1969 A Bahia no século XVIII, Salvador, Ed. Itapuã, 3v.

\begin{abstract}
This article discusses the relationship between transvestites and clothing in 19th century Bahia. The author examines police persecution of transvestites (in their majority men). The argument is that the carreer of transvestites in 19th Brazil depended on the interrelation between the creation of difference through the use of a specifing dressing style and normative sexual roles.
\end{abstract}

KEYWORDS: transvestite, clothing, Bahia, 19th century.

Aceito para publicação em junho de 1997. 